\title{
Preface to the Special Issue on Psychology and the Other
}

\author{
Heather Macdonald • David M. Goodman
}

Published online: 29 June 2012

(C) Springer Science+Business Media, LLC 2012

Scholars in the Western philosophical traditions have defined themselves as seekers and knowers of truth. The Jewish Lithuanian philosopher Emmanuel Levinas (1998) describes this as the "love of wisdom" that underlies Greek and Western philosophical lineages. In modern thought, this seeking and knowing has radicalized to the degree that privilege is given to "knowledge" as a primary means to the true and the good. Toulmin (1990) understood this to be a historic shift to a "quest for certainty." Psychology, beginning with Freud, has largely followed a similar path. From a psychological perspective, the human person is understandable, graspable, measurable, conceivable, and predictable, able to be mapped onto specific, identifiable data points. We are empirically validated selves who relate to empirically validated others. This has often meant that researchers, scholars, and clinicians in the field of psychology have gravitated toward universal systems of 'truth' (Cushman 1995) that can identify correlates of mental anguish in the interior, intrapsychic, or biological processes of an individual. These models of distress create anemic depictions of human relations and contribute to a stifling of larger moral, political, and social truths that can extend into and are given expression through individual and intersubjective experiences (Cushman 1995; Fromm 1955; Laing 1969).

In recent years, there has emerged an increasing number of scholars who call into question the imperialisms of the self and who have identified what Thomas Carl Wall (1999) described as "an extreme humility and an unprecedented ethics" that has ruined "the grand epoch of the Subject and its maniacal striving after itself" (p. 40; see also Brueggemann 1999). The knowing and centralized self - a creation of the modern era-is being called into question (Taylor 2007) within an articulate literature that revolves around the notion of the "Other." The Other - taking many shapes and forms throughout contemporary scholarship - has emerged in critical theory, philosophy, psychology, theology, religious studies, and anthropology. It is a topic ripe for interdisciplinary conversation-a conversation to which this special issue is devoted.

H. Macdonald $(\square)$

Lesley University, 29 Everett St., Cambridge, MA 02138, USA

e-mail: hmacdona@lesley.edu

D. M. Goodman

Harvard Medical School, Lesley University, Cambridge, MA, USA 
Consistent throughout much of this literature is an undoing of the hegemony of the "self" dominated by an ego-centric orientation. The source of this undoing is a re-orientation toward the Other - a recognition of that which exceeds and lives outside of the solipsism of the self. The history of psychology is a history of the human mind and its reluctance to let go of itself; the project of knowledge must give way to the project of ethical obligation to the other. The concept of the Other moves us beyond the mere felt-presence of another person's subjectivity and refers to the idea that "the oneself cannot form itself" (Wall 1999, p. 41), that we can only become a person through other persons.

These are some of the ideas that inspired approximately 300 psychologists, philosophers, and scholars in religious studies and theology to convene in October of 2011 at the "Psychology and the Other" conference in Cambridge, Massachusetts. In attendance were people from national and international institutions who represented multiple disciplines of practice as well as academic inquiry. The conversations and papers exchanged were an interdisciplinary dialogue and exploration of the Other. Researchers and scholars who were typically separated and isolated within small pockets of specialization came to realize that there is a growing hunger for deeper realizations about the phenomenology of self and Other and what is constituted in this relation. The collaborative culture of the conference, combined with the outstanding scholarship, made the whole experience a success. The conference generated high-quality papers and presentations, some of which we share in this special issue.

In this issue, we gathered ten manuscripts that represent some of the major themes and emergent conversations that took place at the conference. In the following paragraphs, we provide a brief description of the pieces.

In his article "Langue, Parole, et Chanson: On Language as Song in Psychoanalysis and Jewish Philosophy," Michael Oppenheim describes a unique dialogue between three postFreudian psychoanalysts (Hans Loewald, Stephen Mitchell, and Thomas Ogden) and three Jewish philosophers (Franz Rosenzweig, Martin Buber, and Emmanuel Levinas) in order to demonstrate that language as "a system and performance fails to capture its sensory, affective, formative, dialogical, ethical and even metaphysical features." Drawing on the knowledge of these scholars, Oppenheim then moves into a discussion on how language-assong illustrates ways in which the self and other live in a rich, textured, affective milieu of breath, rhythm, and silence rather than mere gestured and symbolic performances.

Frank Richardson and Nicolette Manglos offer a critique of René Girard's mimetic theory in their article "Reciprocity and Rivalry: A Critical Introduction to Mimetic Scapegoat Theory." The authors examine the possibility that the hermeneutic philosophies of HansGeorg Gadamer and Mikhail Bakhtin — combined with mimetic theory-may offer a more robust account of human responsibility, especially as humans are faced with the difficulties of envy, greed, enmity, and violence.

In his article "Three Views of Otherness," Bernard Reginster surveys several different depictions of Otherness in relationship to narcissism, ultimately arguing that the "experience of the freedom of the Other" is a core aspect of personhood. First, Reginster discusses psychoanalytic conceptualizations of the Other as narcissistic loss, when the other-as-object fails to gratify the subject. In the next section, he outlines the other as a form of intersubjective engagement based upon the "enjoyment of difference." The final formulations of the paper include an exploration of more current ideology within philosophical psychology around the idea of the person who is able to experience the freedom of the Other.

Joel Pearl, in "Temporal Foundation of Self and Other: A Phenomenological Reading of Narcissism," addresses issues of narcissistic loss by returning to the psychoanalytic "primordial stage of narcissism" and then offering an alternative picture by including the notion 
of temporality as a necessary dimension to understanding the self in relationship to the Other.

Pia Chaudhari, in "Freedom for Relationship: An Initial Exploration of the Theology of Zizioulas and the Psychoanalytic Insights of Winnicott in Dialogue," addresses the longoverlooked subjects of sin, faith, and redemption within the field of psychoanalysis and explores how theological concerns emerge in the process of psychic healing by drawing on the theology of John D. Zizioulas. Her ideas are further elaborated upon through a crossfertilization of the theology of Zizioulas with Donald Winnicott's theories of human development. The concepts of the "False Self" and "True Self" are viewed in the context of communion and redemption and the formation of authentic relationship.

Robert Reed, in "A Lacanian Ethics of Non-Personal Responsibility," uses the ethics and theology of Simone Weil to critique Lacan's formulation of the subject. He writes, "Lacan's critics must therefore respond to Weil's contention that ethics requires almost no 'self' at all." Drawing from Weil's ethics of "decreation," Reed argues that the ethical relationship is derived from a non-personal, symbolic understanding of subjectivity.

Susana McCune, in her article "Living Beyond the Other," provides a powerful autoethnography of her personal experiences around familial loss. Using the works of Martin Heidegger and Emmanuel Levinas, McCune highlights some of the phenomenological dimensions resident in experiencing the death of an Other.

Caleb Hendrickson also writes about death and the Other by using both Franz's Rosenzweig's theology and Jacques Lacan's psychoanalytic theory. In "The Neighbor between Rosenzweig and Lacan," he compares their respective assumptions in terms of how death reveals different ethical attitudes towards the Other.

Paul Cantz and Kalman Kaplan, in "Cross-Cultural Reflections on the Feminine 'Other': Hebraism and Hellenism Redux," discuss the historical dominance of Hellenistic and Greek thought as it contributes to our understandings of relationships between men and women. Cantz and Kaplan conduct an epistemological critique of biblical and Greek views of women and exhort the reader to a more careful understanding of biblical tradition, arguing that such a reading stands against many common depictions of Hebrew Scripture as stigmatizing of women and as misogynistic.

Robert Piehl and Maria Austin, in their article "Psychoanalytic Interpretation as Pharmakon: Applying Derrrida's 'Plato's Pharmacy' to Psychoanalysis," examine the Greek notion of the pharmakon as discussed by Jacques Derrida and consider how one might apply this understanding of interpretive processes in the psychoanalytic context. They conceptualize the process by which interpretation may be experienced by the patient as both a remedy and a poison. Negative therapeutic reaction, then, may actually facilitate or represent an important dimension of a deeper analysis of context-dependent meaning from the patient's perspective.

We greatly appreciate Pastoral Psychology's devotion of a special issue to the "Psychology and the Other" conference. We want to thank, in particular, Dr. Lewis Rambo and Kathy McKay for their editorial guidance and ongoing support in the process of putting together this special issue. We also express a special thanks to our authors who created such highquality work and to the many conference attendees from all over the world who made this conversation possible. We are grateful for the conference's editorial board who did exceptional work in reviewing manuscripts. Thank you, George Horton, Brian Becker, Steven Huett, Martha Reineke, Frank Richardson, Alvin Dueck, Eric Severson, William Adams, Peter August, and Marsha Hewitt, for this service.

With a second "Psychology and the Other" conference scheduled for October 4-6, 2013, it is our hope that these conversations continue and that this type of interdisciplinary dialogue might 
provide an opportunity to enrich and vitalize our respective psychological, theological, and philosophical disciplines. We appreciate Pastoral Psychology's devotion to this project and investment in this ongoing conversation.

\section{References}

Brueggemann, W. (1999). The covenanted self: Explorations in law and covenant. Minneapolis: Fortress Press.

Cushman, P. (1995). Constructing the self, constructing America: A cultural history of psychotherapy. Garden City: DaCapo Press.

Fromm, E. (1955). The sane society. New York: Henry Holt and Company.

Laing, R. D. (1969). The divided self. New York: Penguin.

Levinas, E. (1998). Otherwise than being: Or, beyond essence. Trans. A. Lingis. Boston, MA: M. Nijhoff. (Orig. pub. 1974).

Taylor, C. (2007). A secular age. Cambridge: The Belknap Press.

Toulmin, S. (1990). Cosmopolis: The hidden agenda of modernity. Chicago: University of Chicago Press.

Wall, T. C. (1999). Radical passivity: Levinas, Blanchot, and Agamben. New York: State University of New York Press. 